\title{
Assessing climate change impacts on water balance in the Mount Makiling forest, Philippines
}

\author{
E A Combalicer ${ }^{1,2}, \mathrm{R}$ V O Cruz ${ }^{3}, \mathrm{~S} \mathrm{LeE}^{4}$ and $\mathrm{S} \mathrm{Im}^{4, *}$ \\ ${ }^{1}$ College of Forestry, Nueva Vizcaya State University, 3700 Bayombong, Nueva Vizcaya, Philippines. \\ ${ }^{2}$ Department of Forest Sciences, College of Agriculture and Life Sciences, Seoul National University, \\ 599 Gwanangno, Gwanak-gu, Seoul, 151-921, Korea. \\ ${ }^{3}$ College of Forestry and Natural Resources, University of the Philippines Los Banos, \\ College, Laguna, Philippines. \\ ${ }^{4}$ Department of Forest Sciences, Research Institute for Agriculture $\&$ Life Sciences, College of Agriculture \\ and Life Sciences, Seoul National University, 599 Gwanangno, Gwanak-gu, Seoul, 151-921, Korea. \\ *e-mail: junie@snu.ac.kr
}

\begin{abstract}
A statistical downscaling known for producing station-scale climate information from GCM output was preferred to evaluate the impacts of climate change within the Mount Makiling forest watershed, Philippines. The lumped hydrologic BROOK90 model was utilized for the water balance assessment of climate change impacts based on two scenarios (A1B and A2) from CGCM3 experiment. The annual precipitation change was estimated to be $0.1-9.3 \%$ increase for A1B scenario, and -3.3 to $3.3 \%$ decrease/increase for the A2 scenario. Difference in the mean temperature between the present and the $2080 \mathrm{~s}$ were predicted to be $0.6-2.2^{\circ} \mathrm{C}$ and $0.6-3.0^{\circ} \mathrm{C}$ under $\mathrm{A} 1 \mathrm{~B}$ and A2 scenarios, respectively. The water balance showed that $42 \%$ of precipitation is converted into evaporation, $48 \%$ into streamflow, and $10 \%$ into deep seepage loss. The impacts of climate change on water balance reflected dramatic fluctuations in hydrologic events leading to high evaporation losses, and decrease in streamflow, while groundwater flow appeared unaffected. A study on the changes in monthly water balance provided insights into the hydrologic changes within the forest watershed system which can be used in mitigating the effects of climate change.
\end{abstract}

\section{Introduction}

Changes in climate regime can influence the natural processes of a watershed ecosystem (Band et al 1996; IPCC 2001a) and have long-term implications on economic and ecological processes (USEPA 2004). Nowadays, consensus is that the average global surface temperature has increased by as much as $0.74^{\circ} \mathrm{C}$ during the 20th Century (UNEP 2007; IPCC 2007) and the average sea level has risen approximately to $15-20 \mathrm{~cm}$ during the last century (IPCC 2001b; USEPA 2004). Although climate change can occur naturally, population growth and fossil fuel burning plus high deforestation rate (FAO 2007) have accelerated the increase of greenhouse gases (carbon dioxide, methane, nitrous oxide, and chlorofluorocarbons) in the atmosphere that trap heat and warm the earth system (USEPA 2004).

Increasingly reliable regional climate change projections are now available for many regions of the world due to advances in modelling and understanding of the physical processes of the climate system (Christensen et al 2007). Currently, the Data Distribution Centre of the Intergovernmental Panel on Climate Change (IPCC) provides link to data of various Global Climate Models (GCM) on related scenarios for impact assessments. However, the predicted climate changes for the selected years will depend greatly on the model and scenario selected.

Keywords. BROOK90 model; CGCM3 experiment; Mount Makiling forest reserve; statistical downscaling; water balance. 
In this study, the newly registered Third Generation Coupled Global Climate Model (CGCM3) (Flato 2005) is considered because of its capability in producing station-scale climate information from GCM-scale output, and it can generate daily weather data ignoring only the leap years. Essentially, the CGCM3 model generates sufficient scenario datasets that can be utilized as input data required by the hydrologic model at the catchment scale level.

The CGCM3 is a Canadian model, a member ensemble and part of the IPCC Fourth Assessment Report (AR4). The model incorporates four experiments with two scenarios for statistical downscaling approach. The Canadian Climate Change Scenarios Network provides datasets that can be used as predictors for statistical downscaling. The CGCM3 model data are an improvement on previous models, mainly updated through introductions to the atmospheric component, which include new treatment of water vapour transport, and cumulus parameterization (Flato 2005). Because of this experiment, more changes of local climate will have significant impact on the hydrological regimes and modelling.

In spite of extensive research on the specific impacts of climate change, research and information on the impacts of climate change on watershed systems remain in their early years (Marshall and Randhir 2007). Hundreds of studies of the potential effects of climate change on river flows have been published in scientific journals, and many more studies have been presented in internal reports. Most studies are for Europe, North America and Australia, with a small number of studies for Asia (Bates et al 2008). For instance, Fowler et al (2007) recently wrote a review on advances in downscaling techniques for hydrologic modelling that covered an extensive range of the strengths and weaknesses of downscaling methods for different climatic variables in different regions and seasons. The investigation featured geographical distribution of statistical downscaling studies and methods employed but did not mention the use of statistical downscaling tools in Asia. Nonetheless, some studies have utilized statistical downscaling approaches, including those of Anandhi et al (2008) in Malaprabha reservoir in Karnataka state of India, Asokan and Dutta (2008) in Mahanadi river basin in India; Ghosh and Mujumdar (2008) with relevance vector machine approach in Mahanadi river basin in India; Tripathi et al (2006) with support vector machine in India; Karamouz et al (2007) in Iran; Chen et al (2006) in subtropical region in China; and Wilby et al (1998) in Suwa Lake, Japan.

In hydrologic modelling, many researchers have discussed the use and application of different hydrologic models such as water balance, regression analysis, energy budget and other empirical models (Tabios 1978; Arnell 1999; Vogel et al 1999; Fleming and Neary 2004; Young 2006; Bari and Smettem 2006). The application of a typical hydrologic model requires calibration and parameter fitting for a given site. Applications of BROOK90 model, used in this study, have been demonstrated in grassland (Federer 2002), temperate evergreen and deciduous forests (Federer 2002), monoculture conifer stands into mixed or pure deciduous (Armbruster et al 2004), cultivated land (Wahren et al 2007), silver fir-beech forest (Vilhar et al 2006), mixed Norway spruce and European beech (Jost et al 2005), and mixed coniferous forest (Combalicer et al 2008) with satisfactory performance. The model might also be applicable in tropics after adjusting sensitive parameters to local conditions. In the Philippines, in particular, application of the BROOK90 model remains valuable for watershed management research in view of limited researches and published reports dealing with hydrology of the forest watershed (Environmental Forestry Program 2002).

The Mount Makiling forest reserve is a wellstudied and well-researched ecosystem (Bantayan 2001). Most of the previous investigations were on water quality and sediment characteristics (Pasa 1997), hydrometeorological characterization (Cruz 1982; Saplaco and Aquino 1991), microclimate profile (Saplaco 1983), canopy hydrology (Palis 1991), forest land use change on agricultural production (Anunciado 1993), land capability classification and land use suitability assessment (Pudasaini 1993), land use modelling (Bantayan and Bishop 1998), socio-economic variables of land use changes (Vallesteros 2002), carbon stocks assessment (Lasco et al 2004), ecosystem structure and function (Lee 2006), and stand structure, soil respiration and properties (Bae 2008). Hence, it is timely to study hydrologic behaviours of Mt. Makiling forest watershed in response to climate change.

This study investigated and evaluated the climate change anomalies and trends in the study area using a well-recognized statistical downscaling approach. In addition, BROOK90 model was used to determine the current water balance, and simulated water balance fluxes in response to two climate change scenarios.

\section{Data used and methodology}

\subsection{The study area}

The rainforest of the Makiling Forest Reserve (MFR) is the southern part of Metro Manila, 


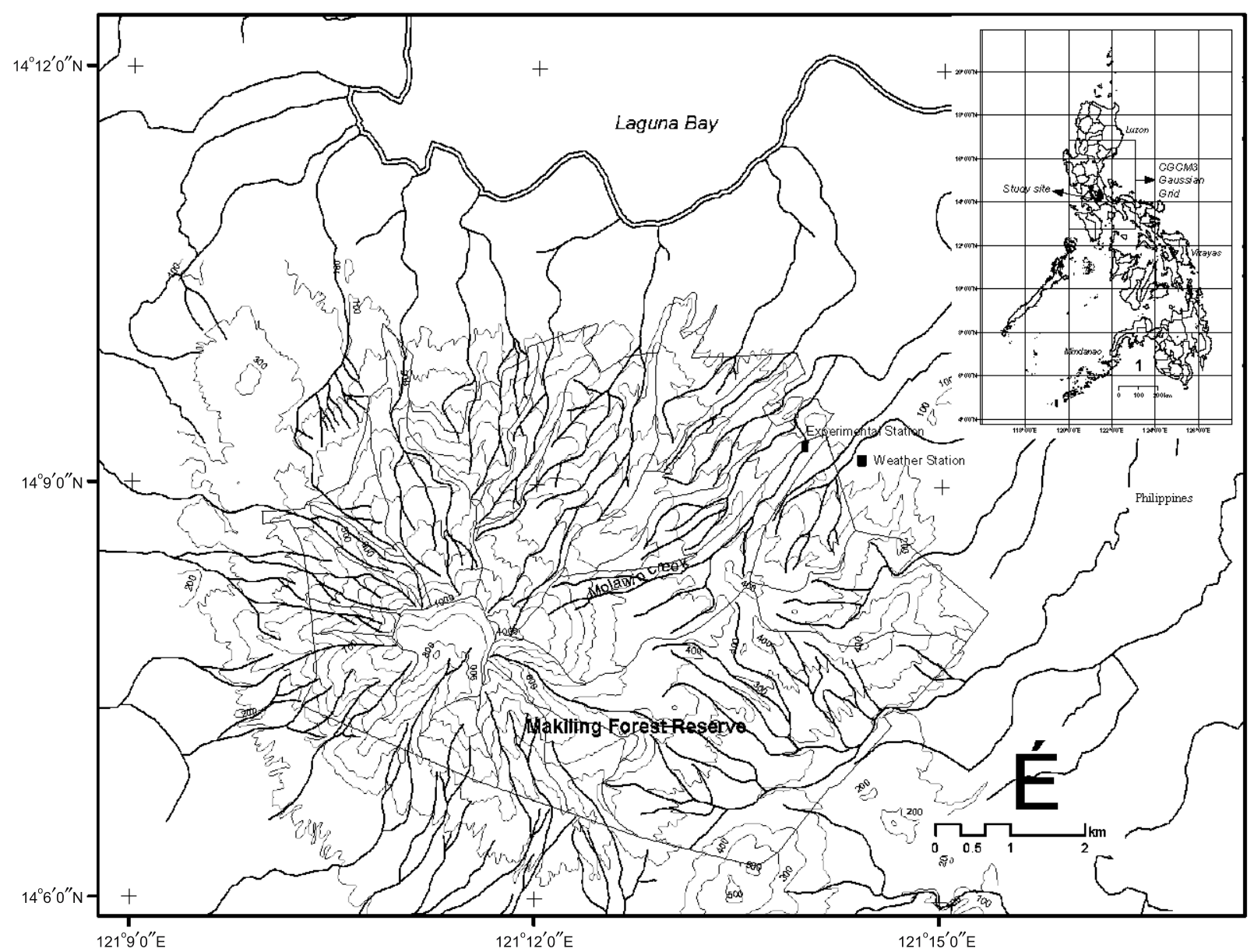

Figure 1. Location of the study site and monitoring stations within the Mt. Makiling forest reserve, Philippines.

Luzon Island, Philippines (figure 1). The forest reserve geographically radiates to coordinates of $14^{\circ} 08^{\prime} 14^{\prime \prime}$ north latitude and $121^{\circ} 11^{\prime} 33^{\prime \prime}$ east longitude. The MFR is only about $42.44 \mathrm{~km}^{2}$ and under the jurisdiction of the University of the Philippines - Los Baños (UPLB). The forest reserve is classified as a national park and it is a critical watershed for power generation (Vallesteros 2002).

There are more than 60 perennial and intermittent streams with a total length of around $89 \mathrm{~km}$ within MFR. The drainage pattern of the Mt. Makiling is radial in appearance which is typical of volcanic landforms. Most tributaries in the area drain to the Laguna de Bay - the Philippine's largest lake. The experimental site is situated within the Molawin forest watershed, a landscape unit with fully vegetated areas, and covering about $3.77 \mathrm{~km}^{2}$.

The topography of Mt. Makiling is generally rugged with elevation ranging from 40 to 1100 meters above sea level (m asl). About $70 \%$ of the total area has an elevation of more than $400 \mathrm{~m}$ asl. The areas at lower elevations have gentle slopes and therefore suitable for farming and settlement. The soils of Mt. Makiling belong to four series (Lipa,
Macolod, Gulugod and Makiling) and are generally fertile. Clay loam is the dominant soil texture in the study site.

The favourable soil and climate makes the forest reserve a rich museum of valuable plant species. The vegetation of Mt. Makiling is a gradient from a parang vegetation at the base, to a typical tall forest on the lower elevations, to a crooked, stunted mossy forest at its three peaks (Fernando et al 2004). The forest reserve contains at least 225 families and 2038 species of vascular plants (Pancho 1983) and may serve well as a representative of the Philippine mixed hardwood vegetation. The botanic gardens harbour many exotic and locally introduced species of plants, which add up to the floral diversity in the area.

The MFR has an annual mean temperature ranging from $25.9^{\circ} \mathrm{C}$ to $29.3^{\circ} \mathrm{C}$ with hottest temperature during the months of April to July while coldest during December to February. The climate is determined primarily by the east and west monsoons and by the movement of intertropical convergence zone. The average annual rainfall recorded at the nearest national weather station (800 $\mathrm{m}$ downstream of the monitoring site) 
ranged from $1645 \mathrm{~mm}$ to $2299 \mathrm{~mm}$ for the past five years.

\subsection{Downscaling process}

The general theory, limitations and practice of downscaling have been discussed in detail in a number of papers (Khan et al 2006; Fowler et al 2007; Wilby and Dawson 2007; Ghosh and Mujumdar 2008). Downscaling methodologies can be broadly classified into four main types (Wilby and Dawson 2007; Ghosh and Mujumdar 2008): dynamical climate modelling, synoptic weather typing, stochastic weather generation and transfer-function approaches. Dynamical downscaling involves the nesting of a higher resolution Regional Climate Model (RCM) within a coarser resolution GCM. The RCM uses the GCM to define time-varying atmospheric boundary conditions around a finite domain, within which the physical dynamics of the atmosphere are modelled using horizontal grid spacing of $20-50 \mathrm{~km}$. Weather typing approaches involve grouping local, meteorological data in relation to prevailing patterns of atmospheric circulation. Climate change scenarios are constructed, either by re-sampling from the observed data distributions (conditional on the circulation patterns produced by a GCM), or by generating synthetic sequences of weather patterns and then re-sampling from the observed data. Weather generators are statistical models of observed sequences of weather variables. They can also be regarded as complex random number generators, the output of which resembles daily weather data at a particular location (Katz and Parlange 1996). The most popular approach of downscaling is the use of transfer function which is a regression based downscaling method (Wilby et al 2004; Tripathi et al 2006).

Statistical downscaling approaches have recently emerged as a means of relating large-scale atmospheric predictor variables to local or station scale meteorological series, which could be used as input to hydrological models (Dibike and Coulibaly 2005; Bates et al 2008). Basically, regression-based downscaling methods rely on direct quantitative relationship between the local scale climate variable (predictand) and the variables containing the larger scale climate information (predictors) through some form of regression functions (Karl et al 1990).

Individual downscaling schemes differ according to the choice of mathematical transfer function, predictor variables or statistical fitting procedure. Linear and nonlinear regressions, artificial neural networks, canonical correlation and principal component analysis have been used to derive predictor-predictand relationships (Conway et al 1996; Schubert and Henderson-Sellers 1997). Lately, Diaz-Nieto and Wilby (2005), and Wilby and Dawson (2007) enlisted the advantages of the statistical downscaling method to obtain stationscale climate information from GCM-scale output as:

- computationally cheap,

- readily transferable from one watershed to another,

- allows using ensembles of climate scenarios,

- permits risk/uncertainty analyses, and

- applicable to 'exotic' predictands such as air quality and wave heights.

However, the model often explains only a fraction of the observed climate variability especially when the predictand is precipitation.

In this study, Statistical Downscaling Model (SDSM) was used to downscale hydrologic variables. Technical details, including model validation and usage, are described by Wilby et al (2001) and Wilby and Dawson (2007). The SDSM has been widely used for the generation of multiple climatic variables in hydrological impact assessment. SDSM simulates climatic variables only at single site (Fowler et al 2007) which was suitable for our study area.

\subsubsection{Predictors}

Predictors are large-scale climate variables used by statistical downscaling tools to generate local variables or predictands (observed fields). The variables from CGCM3 were downloaded from the data access integration website (http://loki.ouranos.ca/DAI/DAI-e.html). The predictor variables were supplied on a grid box by grid box basis in a zip file. Subdirectories were created during the unzipping process and these subdirectories contained the predictors needed to run SDSM. The directory contained 40 years of daily predictor data, derived from the NCEP reanalyses, and normalized over the 1961-1990 period. These data were interpolated to the same grid as CGCM3 (Gaussian grid) before the normalization. Another directory contained 100 years of daily GCM predictor data, normalized over the 1961-1990 period, and covering the future period 2001-2100 of the Special Report on Emissions Scenarios (SRES) A2 and A1B scenarios.

The Mt. Makiling forest reserve area is registered within the grid box $33 \mathrm{X}-21 \mathrm{Y}$. On the global CGCM3 grid, the box number in the $\mathrm{X}$ direction referred to longitude, and the box number in the $\mathrm{Y}$ direction related to latitude for correspondence between box numbering and longitude-latitude coordinates. The model grid is uniform along 


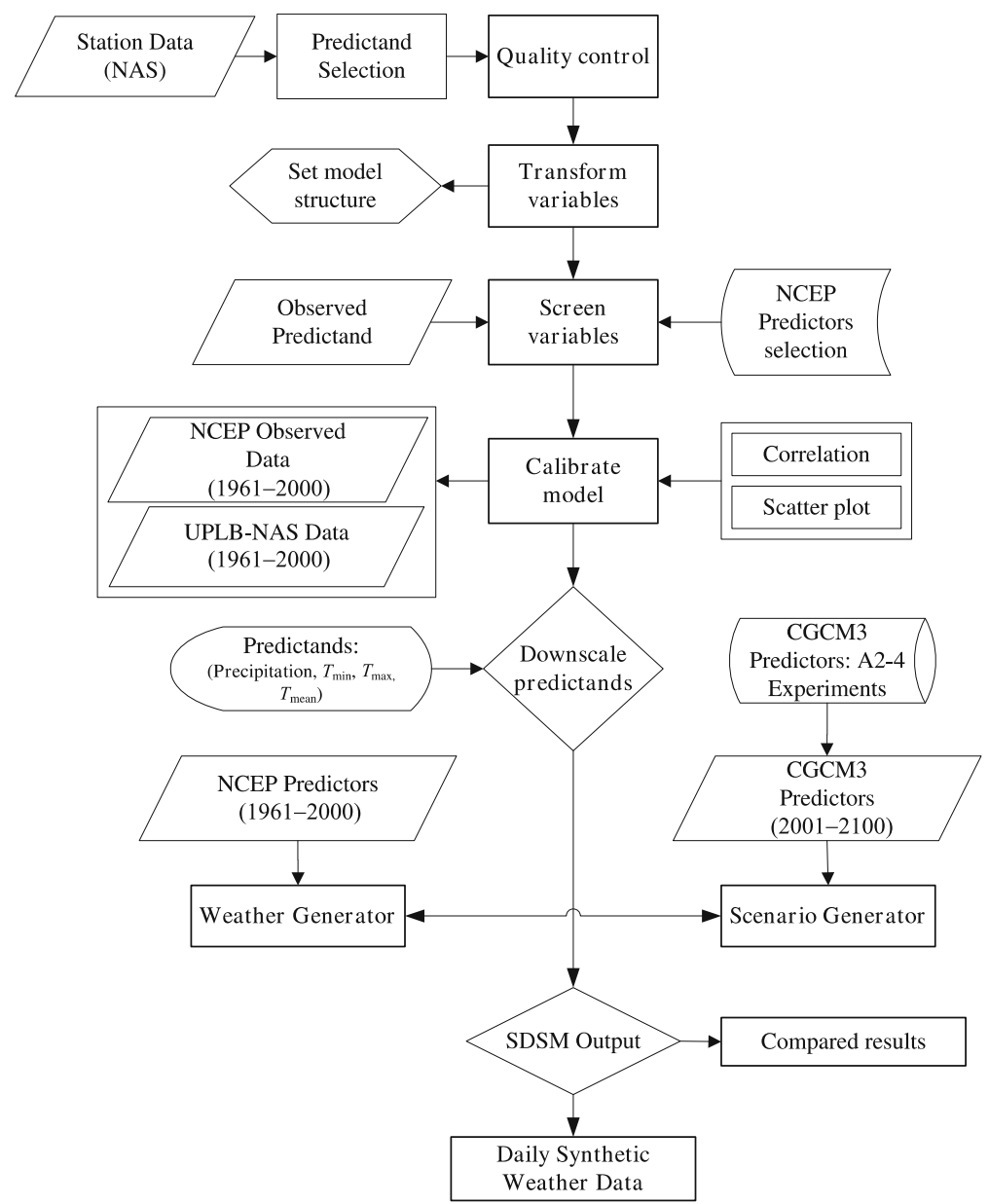

Figure 2. The SDSM downscaling process and the generation of the daily synthetic weather time series for hydrologic modelling based on two scenarios.

the longitude with size of $3.75^{\circ}$ and nearly uniform along the Gaussian latitude (approximately $3.75^{\circ}$ ).

The variables simulated from the third version of the Canadian Centre for Climate Modeling and Analysis (CCCma) Coupled Global Climate Model (Flato and Boer 2001; Flato 2005) at a grid point $\left(12.99^{\circ} \mathrm{N}\right.$ latitude, $120^{\circ} \mathrm{E}$ longitude) were used as predictors. Datasets were extracted at daily time step for A1B and A2 scenarios. According to IPCC SRES A1B and A2 are non-mitigated scenarios driven mainly by increases in anthropogenic greenhouse gas concentration (IPCC 2007). These scenarios cover a wide range of key future characteristics which refer to the driving forces, such as population growth, economic development, and technological change. In particular, the A1B describes a future world of very rapid economic growth, low population growth, and the rapid introduction of new and more efficient technologies. On the contrary, the A2 scenario depicts a very heterogeneous world with low economic development, high population growth, and low technological change when compared to A1B scenario.

\subsubsection{Predictands}

Daily precipitation, and maximum and minimum temperature data were chosen as predictand variables for the downscaling. Forty years (1961-2000) of historical records of predictands were available at UPLB National Agrometeorological Station (NAS) and were used for calibrating and validating downscaling model. Observed daily data of the large-scale predictor variables in place for current climate were obtained from the National Centers for Environmental Prediction (NCEP) reanalysis datasets on the given grid box.

\subsubsection{Calibration and validation of the SDSM}

In SDSM, identifying empirical relationships between gridded predictors and single site predictands is often the most time-consuming process (figure 2). The most relevant predictor variables for downscaling were identified using correlation analysis and scatter plots (between the predictors and the predictand variables). Predictors with 
high correlation were selected based on the analysis output for 12 months. The strength of individual predictors varies from month to month. However, the final choice was made by considering whether the identified variables and their relationships are physically meaningful in the study site. Eventually, the screened predictors were used for the calibration process that constructs downscaling model using multiple regressions.

The observed daily data of large-scale predictor variables representing the current climate condition (1961-2000) derived from the NCEP reanalysis dataset were used to investigate the percentage of variance explained by each predictandpredictor pairs. Two sets of weather data series were prepared. Data series from 1961-1990 were used for calibration, while the remaining 10 years (1991-2000) were used to assess validation performance.

\subsubsection{Scenario generation based on CGCM3 predictors}

Predictands of the two CGCM3 scenarios were generated using the SDSM program as seen in figure 2. In particular, the scenario generator operation in the SDSM program produced ensembles of synthetic daily weather series given atmospheric predictor variables from CGCM3 experiment. Daily time series datasets were synthesized using independent predictors withheld from model calibration for each scenario. The representative time series of present and future climate conditions was produced from the mean ensemble. Thirty ensembles were considered for simulating each scenario. Four distinct periods, namely: the present (2001-2010), the 2020s (covering a 30-year period between 2011 and 2040), the 2050s (2041-2070), and the 2080s (2071-2100) were used for pattern and trend analysis.

\subsection{Hydrologic modelling}

\subsubsection{The BROOK90 model}

The BROOK90 model (Federer 2002) was used for simulating water balance fluxes. The model simulates the precipitation-evaporation-streamflowground water flow for a point scale stand at a daily time-step. The BROOK90 model calculates evaporation with the Shuttleworth-Wallace equation (Shuttleworth and Wallace 1985), an improvement of the Penman-Monteith equation as well as the temporal and quantitative flow mechanisms within a catchment. The soil-water characteristics were defined using a modified approach of the Brooks and Corey (1964), Saxton et al
(1986), and Saxton and Rawls (2006) from 11, 10 and 12 classified textural classes, respectively. The water movement through the soil is simulated using the Darcy-Richards equation. It considers water stored as intercepted rain, intercepted snow, snow on the ground, soil water from one to many layers, and groundwater. Likewise, evaporation is the sum of five components: evaporation of intercepted rain and snow, snow and soil evaporation, and transpiration.

On the other hand, streamflow is generated using the following simplified processes: storm flow by source area flow and delayed flow from vertical or downslope soil drainage and first-order groundwater storage. Further details are provided in the BROOK90 documentation manual (Federer 2002; Federer et al 2003).

In BROOK90 model, the water balance is expressed as follows:

$$
P=E V A P+F L O W+S E E P
$$

where $P$ is the precipitation $(\mathrm{mm}), E V A P$ is the evaporation (mm), FLOW is the corresponding simulated total streamflow $(\mathrm{mm})$ derived from surface flow and the ground water flow, and SEEP is the deep seepage loss from ground water $(\mathrm{mm})$.

The deep seepage loss from the ground water is calculated out as follows:

$$
S E E P=G W A T \times G S C \times G S P,
$$

where GWAT is the groundwater storage below soil layers, $G S C$ is the fraction of groundwater storage that is transferred to ground water flow and deep seepage $(S E E P)$ daily, and $G S P$ is the fraction of ground water discharge produced by $G S C$ that goes to deep seepage and is not added to streamflow.

In this study, ground water flow $(G W F L)$ was assumed to be a first order reservoir as:

$$
G W F L=G W A T \times G S C \times(1-G S P) .
$$

\subsubsection{Data collection}

The water level and flow velocity were measured using a rectangular flume constructed in the area. The float-operated shaft encoder level sensor and logger was installed in the monitoring station to obtain water level, and a digital flow probe was used to measure flow velocity. The measurements during the wet seasons were used to develop stream-discharge relationship in the watershed. 
Table 1. Canopy parameter values of the BROOK90 model calibrated in the watershed.

\begin{tabular}{|c|c|c|c|c|}
\hline Parameters & Description & Range of values & Final value & Source \\
\hline ALB & Albedo (f) & $0.1-0.3$ & 0.25 & Ito and Oikawa (2002) \\
\hline ALBSN & $\begin{array}{l}\text { Surface reflectivity without } \\
\text { and with snow on the } \\
\text { ground (f) }\end{array}$ & $0.1-0.9$ & 0.10 & Ito and Oikawa (2002) \\
\hline KSNVP & $\begin{array}{l}\text { Multiplier to reduce snow } \\
\text { evaporation, arbitrary (f) }\end{array}$ & $0.2-2.0$ & 0.3 & Federer (2002) \\
\hline Z0G & $\begin{array}{l}\text { Ground surface roughness } \\
\quad(\mathrm{m})\end{array}$ & $\geq 0.001$ & 0.02 & Oh (1999) \\
\hline MAXHT & $\begin{array}{l}\text { Maximum canopy height for } \\
\text { the year }(\mathrm{m})\end{array}$ & $>0.01$ & 35 & Direct measurement \\
\hline MAXLAI & $\begin{array}{l}\text { Maximum projected LAI for } \\
\text { the year }\left(\mathrm{m}^{2} / \mathrm{m}^{2}\right)\end{array}$ & $>0.00001$ & 5.31 & $\begin{array}{l}\text { Derived from Landsat } \\
\text { ETM+ } 2002 \text { scene }\end{array}$ \\
\hline MXRTLN & $\begin{array}{l}\text { Maximum length of fine } \\
\text { roots per unit ground area } \\
\left(\mathrm{m} / \mathrm{m}^{2}\right)\end{array}$ & $1700-11000$ & 4000 & Federer (2002) \\
\hline MXKPL & $\begin{array}{l}\text { Maximum plant conductivity } \\
\left(\mathrm{mm} \mathrm{d}^{-1} \mathrm{Mpa}^{-1}\right)\end{array}$ & $5-30$ & 15 & $\begin{array}{l}\text { Federer et al (1996); } \\
\text { Federer }(2002)\end{array}$ \\
\hline FXYLEM & $\begin{array}{l}\text { Fraction of the internal plant } \\
\text { resistance to water flow that } \\
\text { is in the xylem (f) }\end{array}$ & $0-0.99$ & 0.5 & Federer (2002) \\
\hline CS & $\begin{array}{l}\text { Ratio of projected stem area } \\
\text { index (SAI) to HEIGHT (f) }\end{array}$ & $\geq 0$ & 0.035 & Federer (2002) \\
\hline PSICR & $\begin{array}{l}\text { Minimum plant leaf water } \\
\text { potential (Mpa) }\end{array}$ & -1.5 to -3.0 & -2.0 & Federer (2002) \\
\hline GLMAX & $\begin{array}{l}\text { Maximum leaf conductance } \\
(\mathrm{cm} / \mathrm{s})\end{array}$ & $0.2-2.0$ & 0.53 & Federer et al (1996) \\
\hline LWIDTH & Average leaf width $(\mathrm{m})$ & $>0.01$ & 0.10 & $\begin{array}{l}\text { Direct observation and } \\
\text { assumption }\end{array}$ \\
\hline $\mathrm{CR}$ & $\begin{array}{l}\text { Extinction coefficient for } \\
\text { photosynthetically-active } \\
\text { radiation in the canopy (f) }\end{array}$ & $0.5-0.7$ & 0.6 & Federer et al (1996) \\
\hline
\end{tabular}

\subsubsection{Calibration and parameters estimation}

BROOK90 is a parameter rich model which includes location, flows, canopy, soil, fixed and initial values. The model is site specific and has given values for its initialization run. In this study, the main concentration of the calibration and parameter fittings is focused on the canopy, soil, location and flow parameter variables that conform to the appropriate local conditions of a forest watershed. Inputs of climatic variables such as daily precipitation and maximum and minimum temperatures are required, and daily solar radiation, vapour pressure, and wind speed are desirable in the model. Daily average streamflow is also provided as a primary input variable which evaluated the performance efficiency of the BROOK90 model. Two datasets were prepared for the calibration (2004-2006) combining a final set of parameter values and extended for the duration of the validation (2007-2008).

In flow parameter variables evaluation, the morphological characteristics of the watershed were considered. These variables include fast flow components as the sum of flow components, source area flow, bypass flow, and downslope flow in the hydrologic BROOK90 model. In essence, flow variables were greatly associated with streamflow, hydrograph pattern (Brierly and Fryirs 2005), drainage shape and rainfall characteristics (Ramirez 2000).

The values of the different canopy variables were taken from published documents, land satellite imageries and field observations (table 1). The vegetation index using Landsat Enhance Thematic Mapper plus (ETM+) imageries taken in 2002 was utilized to determine the degree of the vigour and density of vegetation at the surface. In addition, the Normalized Difference Vegetation Index (NDVI), an index that provides a standardized method of comparing vegetation greenness among satellite imageries, was considered in correlating the overall maximum leaf area index (LAI) for the entire watershed. The LAI is one of the most important and sensitive parameters in the BROOK90 model, which is 
quite impossible to estimate it in the field with complex vegetation. In effect, vegetation index dynamics in time are correlated with the LAI and other functional variables (Wang et al 2005). The NDVI-LAI relationship for broadleaf canopies has been described in detail by Pullen (2000). Combalicer et al (2008) provide further details of the BROOK90 model sensitivity, parameter estimations and optimization under the small forested watershed.

The soil water parameter values were derived from a modification of the Campbell (1974) expressions with the near-saturation interpolation of Clapp and Hornberger (1978). Soil water parameter values were primarily based on the actual textural classes, organic matter, and bulk density. Soil samples were collected in the watershed from varying soil depths. All required information, such as the matric potential, volumetric water content, matric porosity, negative slope of the log and hydraulic conductivity for the modelling and simulation, were computed from samples using the Saxton and Rawls (2006) approach.

\subsection{Model evaluation criteria}

The coefficient of determination $\left(R^{2}\right)$, NashSutcliffe coefficient $(E)$ (Nash and Sutcliffe 1970), root mean square error (RMSE), and mean absolute relative error (MARE) were used to measure the performance of the SDSM approach and the BROOK90 model. In general, $R^{2}$ value is an indicator of the strength of relationship between the observed and simulated values. $E$ indicates how well the plot of observed versus simulated value fits the 1:1 line. If the values of $R^{2}$ and $E$ are less than or very close to zero, prediction of the modelling system is considered unacceptable or poor. If the values of $R^{2}$ and $E$ are close to one, then prediction of the modelling system is near perfect ( $\mathrm{Li}$ et al 2006). Similarly, the MARE indicates the model's ability to predict the values of a given predictand. The definition of this statistics is:

$$
\operatorname{MARE}=\sum_{i=1}^{n}\left|X_{i}^{\prime} / X_{i}-1\right| / n,
$$

where $X_{i}$ is $i$ th observation, $X_{i}^{\prime}$ is the $i$ th simulation value, and $n$ denotes the total number of data points (observations) in the record. Lower values of MARE and RMSE are preferred.

\subsection{Water balance fluxes to climate change}

Datasets containing the synthetic daily records under the two CGCM3 downscaled scenarios were prepared as input for modelling the future water balance of the Molawin forest watershed. In effect, the BROOK90 model was repeatedly operated using final parameter sets with assumptions that the entire area would not significantly change before the end of the century. The assumption for sustained vegetative conditions of the study area is realistic considering the proclamation guidelines that the area is exclusively devoted for scientific purposes and no further utilization will take place in the future. However, the literature suggests that doubling the atmospheric $\mathrm{CO}_{2}$ concentration leads to a decrease in stomatal conductance of crops and trees by about 24-40\% (Morison 1987; Field et al 1995; Eckhardt and Ulbrich 2003) which induce an average increase in leaf area by about $15-25 \%$ (Pritchard et al 1999; Wand et al 1999). Based on these suggestions, the stomatal conductance and LAI in canopy variables were changed.

\section{Results and discussion}

\subsection{Downscaling daily rainfall and temperature}

\subsubsection{Identifying predictors}

The most appropriate combination of predictors was selected by analysing output of all the 12 months. Table 2 presents the predictor variables identified with monthly correlation between predictand and predictors significant at $5 \%$ level. Results suggest that seven out of 25 predictors namely $p_{--} f, p 5$ th, $p 8_{-} f, s 500, p 850, p 500$, and temp are potentially useful for downscaling precipitation. The relationship of the identified predictors with precipitation varied monthly in which $p 8_{-} f$ represented for January, April, and December, $p_{--} f$ in February and March, $p 5$ th in November, $p 850$ in July and August, and $s 500$ for May and June. In case of downscaling maximum temperature, the percentage of explained variance among predictors was highest and significantly correlated with $p_{--} f$ in October to December, $p 5_{-} z$ in May, $p 500$ in June to September, and temp from January to April. Similarly, the minimum temperature as a predictand responded significantly with shum and temp predictors. The temp predictor has a better performance for the period of April to June, while shum dominated in the remaining months.

Monthly correlations between predictor variables and each predictand (precipitation, $T_{\max }$, and $T_{\min }$ ) have the strongest association once the influence of all other predictors has been removed (table 3). The precipitation correlation coefficients were relatively lower compared to temperatures but significantly associated with predictors except for the month of March $(p=0.085)$. Other investigators expressed the same observation in downscaling 
Table 2. List of predictors from NCEP and CGCM3 datasets and selected predictors (1961-1990) with high monthly correlation corresponding to each of the predictand.

\begin{tabular}{|c|c|c|c|c|c|}
\hline \multirow[b]{2}{*}{ No. } & \multirow{2}{*}{$\begin{array}{l}\text { Predictors } \\
\text { code }\end{array}$} & \multirow[b]{2}{*}{ Description } & \multicolumn{3}{|c|}{ Predictand } \\
\hline & & & Precipitation & $T_{\max }$ & $T_{\min }$ \\
\hline 1 & slpg & Mean sea level pressure & & & \\
\hline 2 & $p_{--} f$ & $1000 \mathrm{hPa}$ Wind speed & $x$ & $x$ & \\
\hline 3 & $\mathrm{p}_{--} \mathrm{u}$ & $1000 \mathrm{hPa}$ U-component & & & \\
\hline 4 & $\mathrm{p}_{--} \mathrm{v}$ & $1000 \mathrm{hPa} \mathrm{V}$-component & & & \\
\hline 5 & $\mathrm{p}_{--} \mathrm{z}$ & $1000 \mathrm{hPa}$ Vorticity & & & \\
\hline 6 & p_th & $1000 \mathrm{hPa}$ Wind direction & & & \\
\hline 7 & p_zh & 1000 hPa Divergence & & & \\
\hline 8 & $\mathrm{p} 5 \_\mathrm{f}$ & $500 \mathrm{hPa}$ Wind speed & & & \\
\hline 9 & $\mathrm{p} 5 \_\mathrm{u}$ & $500 \mathrm{hPa}$ U-component & & & \\
\hline 10 & $\mathrm{p} 5 \_\mathrm{v}$ & $500 \mathrm{hPa} \mathrm{V}$-component & & & \\
\hline 11 & $\mathrm{p} 5 \_z$ & $500 \mathrm{hPa}$ Vorticity & & $x$ & \\
\hline 12 & p500 & $500 \mathrm{hPa}$ Geopotential & $x$ & $x$ & \\
\hline 13 & $\mathrm{p} 5$ th & $500 \mathrm{hPa}$ Wind direction & $x$ & & \\
\hline 14 & p5zh & $500 \mathrm{hPa}$ Divergence & & & \\
\hline 15 & $\mathrm{p} 8 \_f$ & $850 \mathrm{hPa}$ Wind speed & $x$ & & \\
\hline 16 & $\mathrm{p} 8 \_\mathrm{u}$ & $850 \mathrm{hPa}$ U-component & & & \\
\hline 17 & $\mathrm{p} 8 \_\mathrm{v}$ & $850 \mathrm{hPa} \mathrm{V}$-component & & & \\
\hline 18 & $\mathrm{p} 8 \_z$ & $850 \mathrm{hPa}$ Vorticity & & & \\
\hline 19 & p850 & $850 \mathrm{hPa}$ Geopotential & $x$ & & \\
\hline 20 & p8th & $850 \mathrm{hPa}$ Wind direction & & & \\
\hline 21 & $\mathrm{p} 8 \mathrm{zh}$ & $850 \mathrm{hPa}$ Divergence & & & \\
\hline 22 & s500 & $500 \mathrm{hPa}$ Specific humidity & $x$ & & \\
\hline 23 & s850 & 850 hPa Specific humidity & & & \\
\hline 24 & shum & 1000 hPa Specific humidity & & $x$ & $x$ \\
\hline 25 & temp & Temperature at $2 \mathrm{~m}$ & $x$ & $x$ & $x$ \\
\hline
\end{tabular}

Table 3. Summary of the monthly partial correlations $(r)$ for each predictand responding to the identified NCEP predictors (1961-1990) in the site.

\begin{tabular}{|c|c|c|c|c|c|c|}
\hline \multirow[b]{2}{*}{ Month } & \multicolumn{2}{|c|}{ Precipitation } & \multicolumn{2}{|c|}{$T_{\max }$} & \multicolumn{2}{|c|}{$T_{\min }$} \\
\hline & $r$ & $\overline{p \text { value }}$ & $r$ & $\overline{p \text { value }}$ & $r$ & $p$ value \\
\hline January & 0.110 & 0.002 & 0.242 & 0.001 & 0.346 & 0.001 \\
\hline February & 0.190 & 0.003 & 0.355 & 0.001 & 0.358 & 0.001 \\
\hline March & 0.122 & 0.085 & 0.359 & 0.001 & 0.273 & 0.001 \\
\hline April & 0.233 & 0.001 & 0.280 & 0.001 & 0.335 & 0.001 \\
\hline May & 0.106 & 0.037 & 0.219 & 0.001 & 0.272 & 0.001 \\
\hline June & 0.087 & 0.044 & 0.221 & 0.001 & 0.217 & 0.001 \\
\hline July & 0.135 & 0.001 & 0.262 & 0.001 & 0.257 & 0.001 \\
\hline August & 0.084 & 0.047 & 0.335 & 0.001 & 0.286 & 0.001 \\
\hline September & 0.096 & 0.021 & 0.261 & 0.001 & 0.261 & 0.001 \\
\hline October & 0.190 & 0.001 & 0.133 & 0.001 & 0.267 & 0.001 \\
\hline November & 0.159 & 0.001 & 0.148 & 0.001 & 0.301 & 0.001 \\
\hline December & 0.165 & 0.001 & 0.164 & 0.001 & 0.324 & 0.001 \\
\hline Annual & 0.103 & 0.001 & 0.307 & 0.001 & 0.390 & 0.001 \\
\hline
\end{tabular}

precipitation (Diaz-Nieto and Wilby 2005; Dibike and Coulibaly 2005; Wilby and Dawson 2007). In this respect, Khan et al (2006) specified the transformation applied to the predictand in conditional models. As in the case of daily precipitation, it is modelled as a conditional process in which local precipitation amounts are correlated with the occurrence of wet-days, which in turn is correlated with regional-scale atmospheric variables. 
Table 4. The SDSM performance for downscaling precipitation and temperatures using NCEP and CGMC3 predictors and observed predictands during calibration (1961-1990) and validation (1991-2000) periods.

\begin{tabular}{|c|c|c|c|c|c|c|}
\hline \multirow{2}{*}{$\begin{array}{l}\text { Performance } \\
\text { criteria }\end{array}$} & \multicolumn{2}{|c|}{ Precipitation } & \multicolumn{2}{|c|}{$T_{\max }$} & \multicolumn{2}{|c|}{$T_{\min }$} \\
\hline & Calibration & Validation & Calibration & $\overline{\text { Validation }}$ & Calibration & Validation \\
\hline \multicolumn{7}{|c|}{ Predictors: NCEP } \\
\hline$R^{2}$ & 0.94 & 0.89 & 1.00 & 0.97 & 1.00 & 0.98 \\
\hline$E$ & 0.90 & 0.89 & 1.00 & 0.77 & 1.00 & 0.87 \\
\hline RMSE & 1.11 & 1.37 & 0.03 & 0.31 & 0.01 & 0.15 \\
\hline MARE & 1.16 & 1.47 & 1.03 & 1.06 & 1.05 & 1.06 \\
\hline \multicolumn{7}{|c|}{ Predictors: CGCM3 } \\
\hline$R^{2}$ & 0.88 & 0.94 & 0.99 & 0.96 & 0.98 & 0.97 \\
\hline$E$ & 0.79 & 0.94 & 0.98 & 0.71 & 0.97 & 0.89 \\
\hline RMSE & 1.51 & 1.01 & 0.20 & 0.37 & 0.14 & 0.21 \\
\hline MARE & 1.15 & 1.40 & 1.03 & 1.06 & 1.04 & 1.06 \\
\hline
\end{tabular}
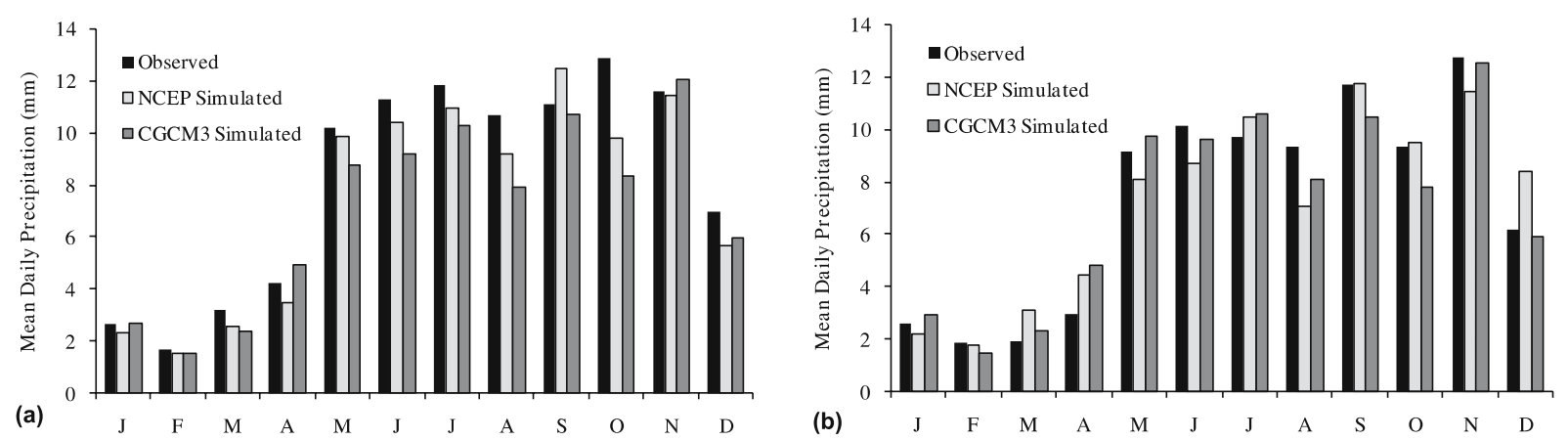

Figure 3. Mean daily precipitation performance using the SDSM approach during (a) calibration (1961-1990) and (b) validation (1991-2000) periods at the study site.

A wet day is defined as a day with nonzero precipitation amount of $0.3 \mathrm{~mm}$ or more. As the distribution of daily precipitation is skewed, a fourth root transformation is applied to the original series to convert it to a normal distribution, and used it in regression analysis.

In contrast, temperatures are modelled as unconditional processes in SDSM, in which a direct link is assumed between the large-scale predictors and local scale predictand. No transformation is applied to daily temperature data which are mostly normally distributed (Wilby and Dawson 2007).

\subsubsection{Calibration and validation of SDSM}

Table 4 shows the SDSM performance for downscaling precipitation and temperatures. The results indicated acceptable response of the model between the observed and simulated (downscaled) predictands such as precipitation, $T_{\max }$, and $T_{\min }$ based on NCEP and CGCM3 predictors in both calibration and validation periods. The different performance criteria showed consistent trend that the model simulated the predictand values reasonably well. The RMSE and MARE constantly gave low agreement between the observed and simulated values during the calibration and validation periods. The calibration and validation results among predictands have shown close relationship with the observations, which indicated the ability of selected NCEP predictors in generating the predictands for the CGCM3 scenarios of the study site.

The mean daily precipitation (average of all values), as shown in figure 3 , ranged from $1.7 \mathrm{~mm}$ to $12.9 \mathrm{~mm}$ (calibration) and 1.9 to $11.8 \mathrm{~mm}$ (validation). The simulated mean daily precipitation using NCEP and CGCM3 had insignificant differences from the observed values, though lower during both calibration and validation periods. This condition can be attributed to the mean dry spell length (average length of spell with precipitation amounts less than the wet-day threshold of $0.3 \mathrm{~mm} /$ day) and mean wet spell length (average length of spell with amounts greater than or equal to the wet-day threshold of $0.3 \mathrm{~mm} /$ day), which were consistently underestimated throughout the year except in July's wet spell.

In general, the simulation of dry and wet spells was less successful because any attempt to increase 

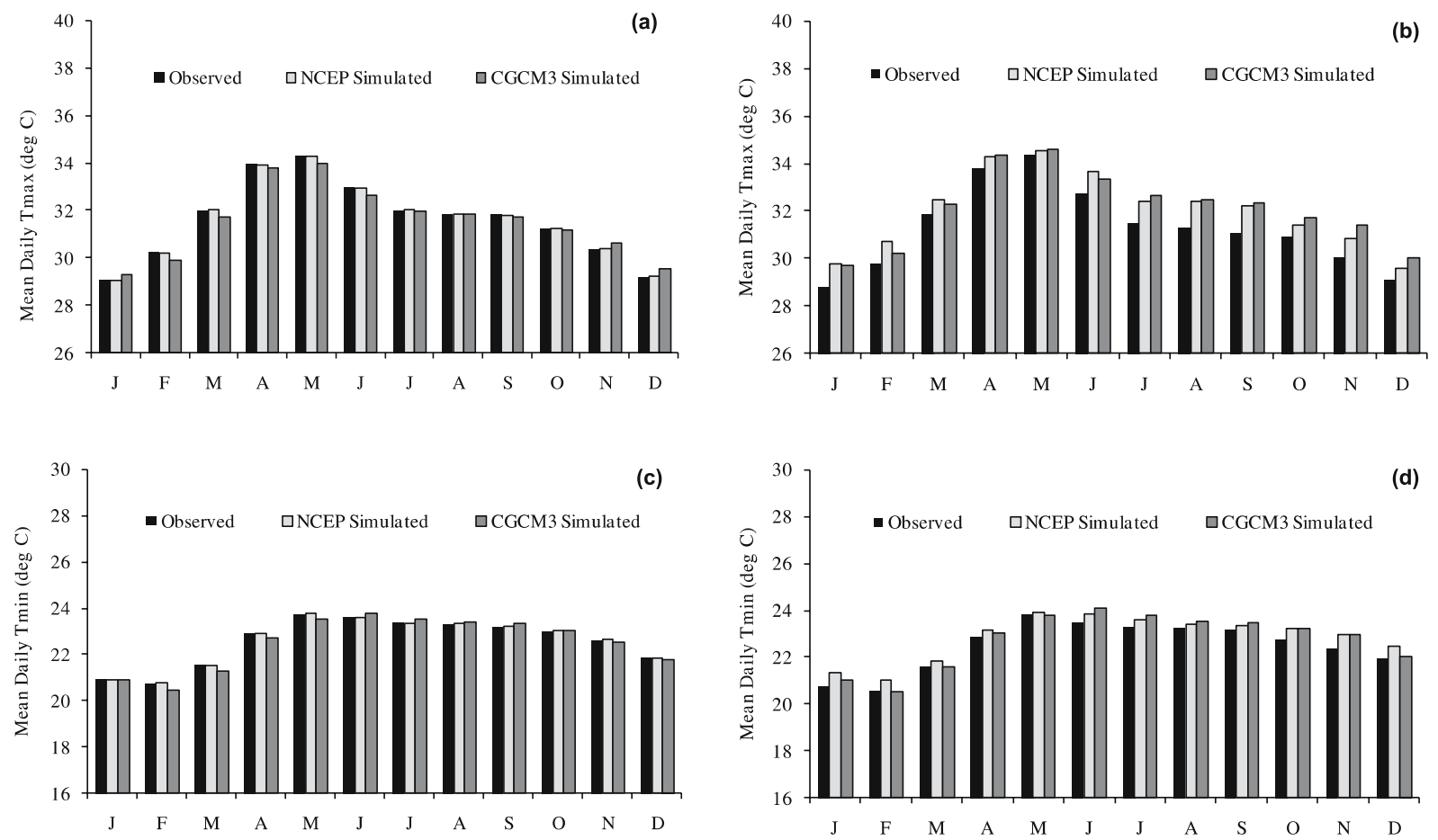

Figure 4. The observed and NCEP and CGCM3 simulated (synthetic) $T_{\max }$ and $T_{\min }$ performance in terms of daily mean for the study site: (a) $T_{\max }$ calibration, (b) $T_{\max }$ validation, (c) $T_{\min }$ calibration, and (d) $T_{\min }$ validation periods.

the length causes a considerable change in other variables, which were initially well calibrated. This may imply that the model still does not fully capture the true persistence of the precipitation occurrence process despite the inclusion of lagged predictors.

In the case of downscaling temperatures, the mean daily minimum temperature estimated ranged from $20.9^{\circ}$ to $24.1^{\circ} \mathrm{C}$, while the maximum temperature ranged from $28.1^{\circ}$ to $34.6^{\circ} \mathrm{C}$ in the site (figure 4). The chosen predictors from the NCEP and CGCM3 indicated a reasonable agreement between the observed and the simulated $T_{\max }$ and $T_{\min }$ of the downscaling model. The SDSM provided insignificant differences in the predicted $T_{\max }$ and $T_{\min }$ values in the given validation period in both NCEP and CGCM3, which were presumed to be associated by a shorter simulation periods.

\subsubsection{Downscaling climate variables}

The selected CGCM3 predictor variables in the two given climate change scenarios were employed in the downscaling process to generate the precipitation and temperature scenarios of the four periods, namely: the present (2001-2010), the 2020s (2011-2040), the 2050s (2041-2070) and the 2080s (2071-2100).

Figure 5 shows the general trend of the change anomalies in monthly precipitation against the observed baseline period (1961-2000).
Change anomalies were estimated as the difference from current or future periodic monthly average precipitation to the observed baseline period monthly average precipitation values. The A1B scenario showed an overall increasing trend in the monthly precipitation particularly in April-May (6.4-55.8 mm) and SeptemberNovember $(10.0-87.9 \mathrm{~mm})$, while consistently decreasing trend was noted during the month of August $(1.8-16.3 \mathrm{~mm})$. The variability of the amount of precipitation is mainly attributed to the shorter dry-spell length during dry seasons (1.8-2.1 days).

In addition, an increasing trend for the wetspell length took place all throughout the year by as much as 5.6 days a month, except from June to August. The precipitation under the A2 scenario, the monthly precipitation pattern varied for different periods. In particular, the monthly precipitation fluctuated from month to month.

However, the most distinct changes were predicted to be in the 2080s period where the months of May, June, and August had indicated a potential decrease of approximately $26-42 \%$ from the baseline period precipitation, while noticeably increased for the duration of October-November $(36-43 \%)$. Other periods closely followed the trends and patterns when compared with the A1B scenario in the study site. The fluctuating changes in monthly precipitation for the A2 scenario are probably due to the disparity of dry-spell length 


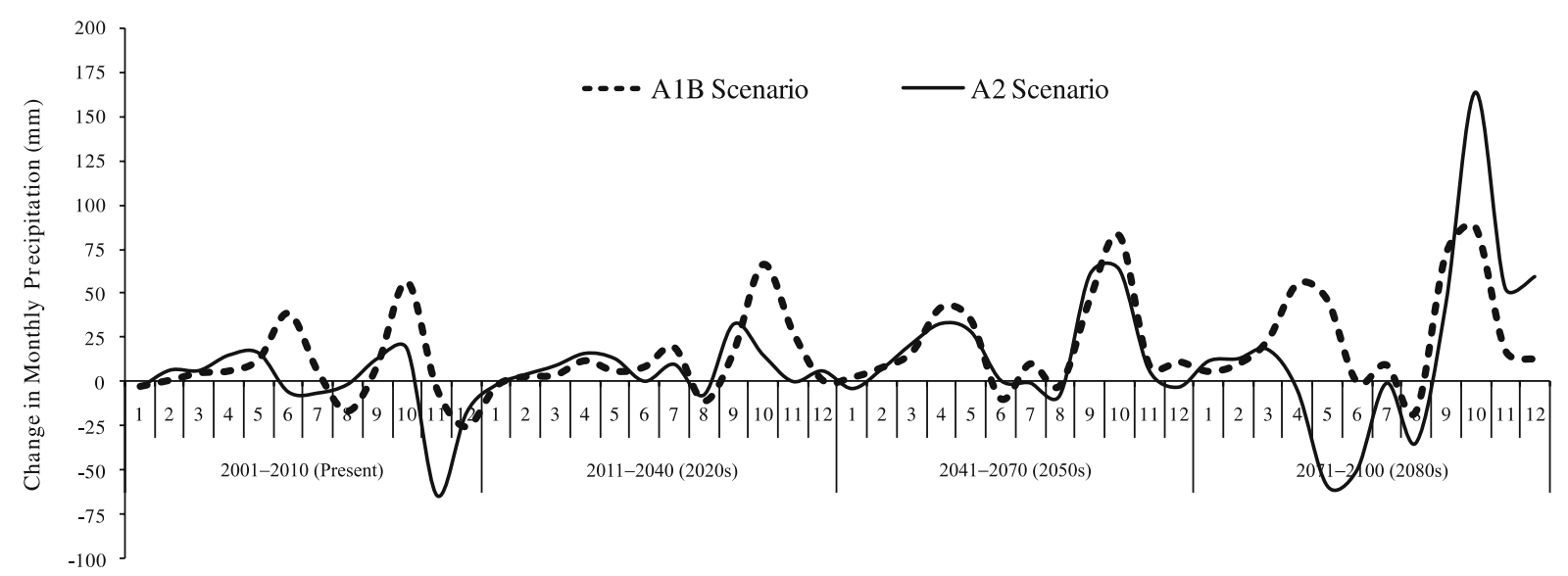

Figure 5. General trend of the change anomalies in monthly precipitation corresponding to A1B and A2 scenarios.

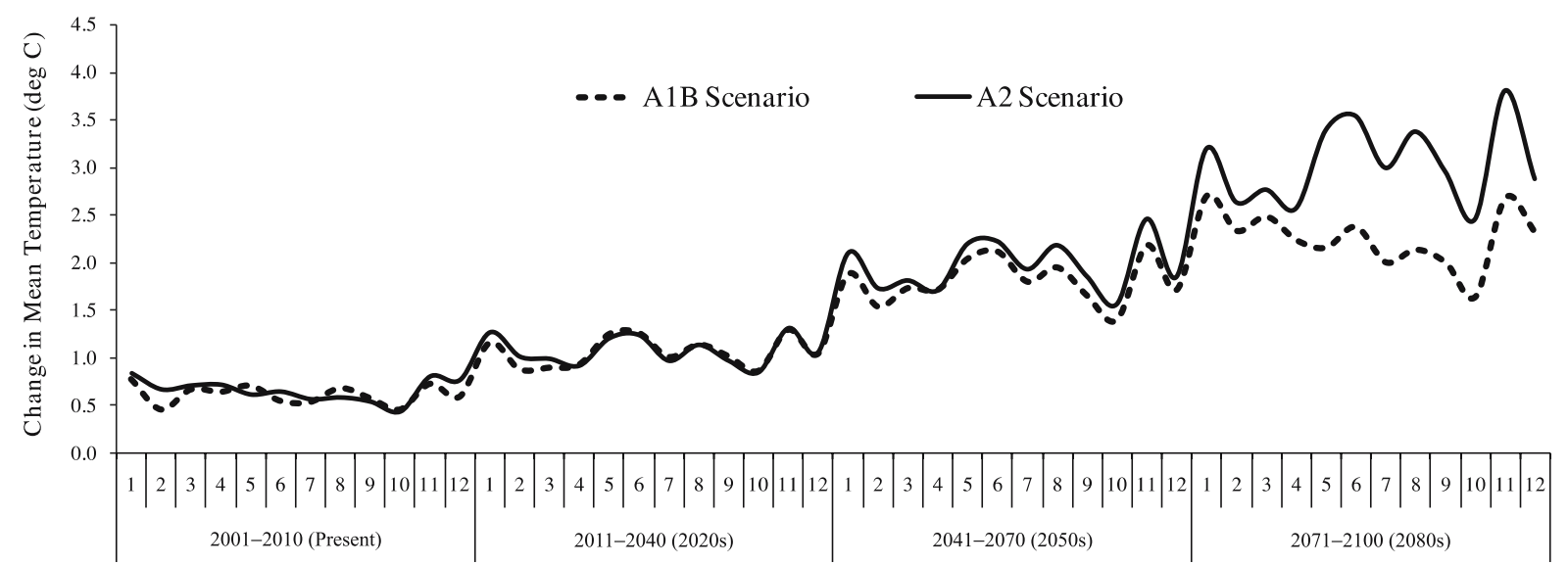

Figure 6. General trend of the change anomalies in temperature corresponding to two climate change scenarios at the study site.

which was shortened from October to March (1.2 to 1.9 days) for all periods but most likely lengthened from April (3.2 days) and May (2.0 days).

Similarly, the influence of wet-spell appeared to be extremely higher throughout the 2080s than in any other period especially from October to December. Hence, there were pronounced seasonal differences even with small increases in annual precipitation around the site in the future.

In effect, the dry seasons tend to become drier, while the wet seasons become wetter. The annual precipitation change was estimated to be 0.1 to 9.3\% increase for A1B scenario, and -3.3 to $3.3 \%$ decrease/increase for the A2 scenario.

Figure 6 shows the change anomalies in the mean temperature in future periods for both scenarios. The A1B scenario estimated an increase of $+0.6^{\circ} \mathrm{C}$ (the present condition) up to $+2.2^{\circ} \mathrm{C}$ by the end of the century, while change anomalies in the A2 scenario predicted an increase of +0.6 in present condition to $+3.0^{\circ} \mathrm{C}$ in the 2080s . The results revealed identical patterns for both scenarios but differences in temperature changes between scenarios are larger from 2050s period and onwards. The increase in local mean temperatures is between $+2.2^{\circ}$ and $+3.0^{\circ} \mathrm{C}$ in 2100 . The changes in temperature were comparable to the projected change estimated by CRU-WWF (1999) in case of the $\mathrm{A} 1$ scenario $\left(+1.8^{\circ} \mathrm{C}\right)$ and A2 scenario $\left(+3.6^{\circ} \mathrm{C}\right)$ within the southern part of Luzon, Philippines.

Likewise, the result of SDSM simulation in temperature time series was slightly lower to the projected mean global warming temperature of $+2.65^{\circ} \mathrm{C}$ for $\mathrm{A} 1 \mathrm{~B}$ scenario and $+3.13^{\circ} \mathrm{C}$ for scenario A2 by 2100 (Meehl et al 2007).

\subsection{Hydrologic modelling}

\subsubsection{Calibration and validation of BROOK90}

The on-site measurements took place over varying periods between 2004 and 2008. The average annual rainfall during the calibration was $1907 \mathrm{~mm}$ and $1940 \mathrm{~mm}$ in the validation period. The period between June to December was classified as a rainy 
Table 5. Performance of the BROOK90 model simulations in a forest watershed.

\begin{tabular}{|c|c|c|}
\hline $\begin{array}{l}\text { Performance } \\
\text { criteria }\end{array}$ & $\begin{array}{c}\text { Calibration } \\
(2004-2006)\end{array}$ & $\begin{array}{c}\text { Validation } \\
(2007-2008)\end{array}$ \\
\hline \multicolumn{3}{|l|}{$\overline{R^{2}}$} \\
\hline Daily & 0.67 & 0.81 \\
\hline Monthly & 0.87 & 0.87 \\
\hline \multicolumn{3}{|l|}{ Seasonal } \\
\hline Dry season & 0.85 & 0.82 \\
\hline Wet season & 0.70 & 0.93 \\
\hline Annual & - & - \\
\hline \multicolumn{3}{|l|}{$E$} \\
\hline Daily & 0.59 & 0.74 \\
\hline Monthly & 0.87 & 0.81 \\
\hline \multicolumn{3}{|l|}{ Seasonal } \\
\hline Dry season & 0.87 & 0.78 \\
\hline Wet season & 0.17 & 0.86 \\
\hline Annual & - & - \\
\hline \multicolumn{3}{|l|}{ RMSE } \\
\hline Daily & 5.91 & 4.17 \\
\hline Monthly & 24.67 & 18.25 \\
\hline \multicolumn{3}{|l|}{ Seasonal } \\
\hline Dry season & 16.01 & 12.98 \\
\hline Wet season & 34.75 & 36.88 \\
\hline Annual & 26.2 & - \\
\hline \multicolumn{3}{|l|}{ MARE } \\
\hline Daily & 0.02 & 0.04 \\
\hline Monthly & 2.12 & 1.05 \\
\hline \multicolumn{3}{|l|}{ Seasonal } \\
\hline Dry season & 3.80 & 0.14 \\
\hline Wet season & 0.92 & 0.90 \\
\hline Annual & 1.02 & 1.03 \\
\hline
\end{tabular}

(wet) season with average monthly precipitation values of greater than $150 \mathrm{~mm}$ during both calibration and validation. The average annual streamflow was lower during the calibration $(899 \mathrm{~mm})$ than the validation $(1131 \mathrm{~mm})$ events with an average of about $947 \mathrm{~mm}$ per year during the five-year observation period.

Table 5 shows the efficiency criteria that described statistical measurements on how well a model simulation fits the available observations. The coefficient of determination $\left(R^{2}\right)$ values in different time scales were high for both periods, indicating a good relationship between the measured and simulated streamflows. Similarly, the simulation showed positive Nash-Sutcliffe coefficients for daily, monthly, and seasonal streamflows.

Conversely, the wet season performance during the validation demonstrated a higher satisfying agreement than the calibration period. This condition can be attributed to the underestimation of the model's performance during peak flows and overestimation during low flows. It should be noted, with due consideration, that the total precipitation in the site was lower during the calibration period. Nash-Sutcliffe efficiency indices implied a good and acceptable relationship between the mean values of observed and simulated streamflows. Hence, validation results for the site indicated that the calibrated parameter values were acceptable in predicting streamflow.

In case of the mean absolute relative errors between the observed and simulated streamflows, the calibration period performance was fairly well, with only 0.02 on daily streamflow, 2.12 for monthly flows, 3.80 for dry season flows, 0.92 for wet season flows, and 1.02 for an annual streamflow. For the validation period, the mean absolute relative error for total streamflow was 1.03 but the seasonal performance was improved to 1.4 for summer flows 0.9 for monsoon flows.

Similarly, a decrease in the root mean square errors between the calibration and validation periods was noted, indicating an improvement in the performance of the model during validation. This improvement is believed to be associated with the continuous rains and early typhoon event during the month of January in 2008. Overall, the simulated streamflows during the dry season are slightly overestimated, while the extreme streamflow peaks during the rest of the year were occasionally underestimated for both calibration and validation periods. This can be attributed to the effects of ground water below the soil layers of the model, which is mainly the source of streamflows in response to the simulation for the period of low flows. Consequently, a small discrepancy on an annual basis was distinguished in high flow simulations throughout the observation periods.

\subsubsection{The current water balance of the watershed}

Figure 7 provides an overview of the annual average water balance components of the Molawin tropical forest watershed for eight years with climatic data. The results are expressed in terms of the water balance components given by equation (1).

On an annual basis, approximately $42.1 \%$ of the precipitation $(1853 \mathrm{~mm})$ is converted into evaporation, $48.1 \%$ into streamflow, and $9.9 \%$ as deep seepage loss. An average streamflow of $1853 \mathrm{~mm}$ was estimated with the two peak flows that occurred in July $(110 \mathrm{~mm})$ and November $(149 \mathrm{~mm})$, while the lowest was recorded in April $(17 \mathrm{~mm})$. The outcomes of the simulation were affected by the increasing rate of surface and saturated ground water flows.

In essence, a large portion of precipitation became streamflow mainly through surface flow $(29.7 \%)$ and ground water flow (18.3\%). The total monthly evaporation losses were roughly $779 \mathrm{~mm}$ with highest in July $(155 \mathrm{~mm})$ and lowest 


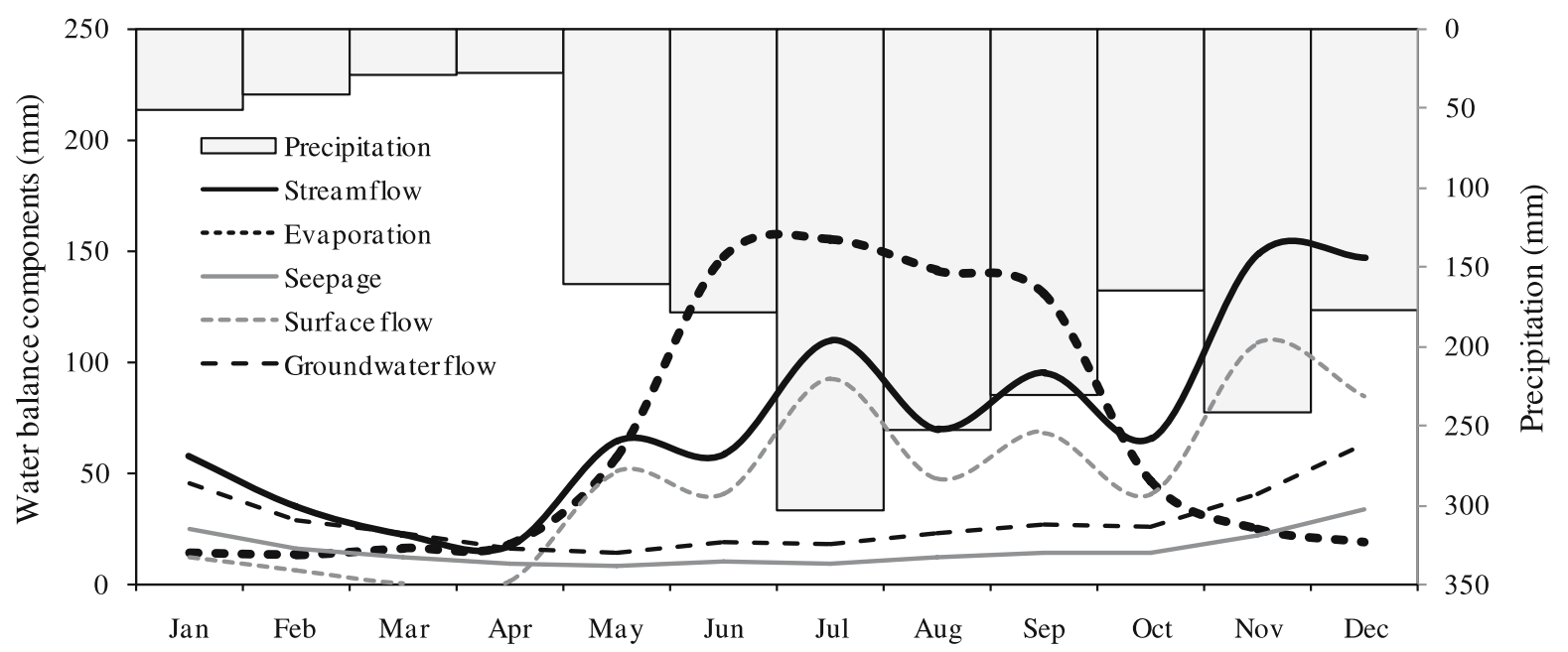

Figure 7. The current water balance in the Molawin watershed based on 8-year climatic data.

in February $(13 \mathrm{~mm})$. The total seepage loss was about $183 \mathrm{~mm}$, which are fairly higher in amounts during the months of November $(22 \mathrm{~mm})$, December $(34 \mathrm{~mm})$, and January $(25 \mathrm{~mm})$, while lower for the rest of the year.

The monthly water balance variations demonstrated how evaporative losses greatly affect the streamflow components of a forested watershed. Evaporation losses were usually high from June to October $(>75 \mathrm{~mm})$ and low during the rest of the year. In addition, the amount of evaporation was higher than streamflow during April to September, equivalent to $36-82 \%$ of the precipitation.

Basically, evaporation losses were mainly coming from transpiration and evaporation from the intercepted rain throughout the rainy season while evaporation from the soil dominated during the dry season. Results indicated that almost $13-65 \%$ of the evaporation was caused by transpiration while 6-14\% was released through evaporation from the intercepted rain. Federer (2002) described that in vegetated systems, evaporation was dominated by transpiration which was controlled largely by maximum leaf conductance when soil remains reasonably wet. About $22-58 \%$ of the evaporation losses was due to soil evaporation during the dry season.

The simulated annual water balance components over a given period in the forest vegetated Molawin watershed were related to the previous investigations. For instance, Cheng et al (2002) reported the annual water balance components of the four forested watersheds in Taiwan, in which the water yield (streamflow) was estimated within a range of $47-56 \%$ and $43-54 \%$ for evapotranspiration, including the $18.7 \%$ interception loss and $24.7 \%$ transpiration. Klinge et al (2001) found a forest total evapotranspiration of about $1350 \mathrm{~mm}$ ( $45 \%$ of the precipitation) in a rain forest region of eastern Amazon, Brazil. Lu and Tang (1995) accounted $11.3 \%$ interception loss to precipitation in the natural hardwood forest at central Taiwan. Mun (1987) estimated forest evaporation losses of $49 \%$ of total rainfall in a large tropical rainforest watershed in Malaysia. Calder et al (1986), for his part, reported a total evapotranspiration of $1481 \mathrm{~mm}$ (52\% of the gross rainfall) in West Java, Indonesia.

\subsection{Water balance fluxes in response to climate change}

Figure 8 presents the general trend of the two CGCM3 key scenarios' streamflow, evaporation losses, and seepage under the tropical forest watershed condition. Given the present streamflow in a watershed $\left(891 \mathrm{~mm} \mathrm{yr}^{-1}\right)$, there would be a lot of extreme conditions as reflected in both scenarios for the future. The estimated average periodic streamflows were about $757 \mathrm{~mm}$ (the $2020 \mathrm{~s}$ ), $832 \mathrm{~mm}$ (the 2050s), and $847 \mathrm{~mm}$ (the $2080 \mathrm{~s}$ ) for the A2 scenario and $811 \mathrm{~mm}$ (the 2020s), $878 \mathrm{~mm}$ (the 2050s), and $958 \mathrm{~mm}$ (the 2080s) in the A1B scenario.

In particular, the early and late parts of the 2020s period showed a higher streamflow in the A1B scenario, while the A2 scenario predicted the same periodic streamflows in the early years and substantially lower values in the remaining years.

The estimated streamflows in the 2050 s period showed extreme streamflows events in watershed. The A2 scenario more often responded to the fluctuation in streamflows throughout the period while the A1B scenario exhibited mostly averageto-high flows during the middle part of the period. The 2080s simulation resulted in most likely extreme dry streamflows for many consecutive years particularly in the A2 scenario. 

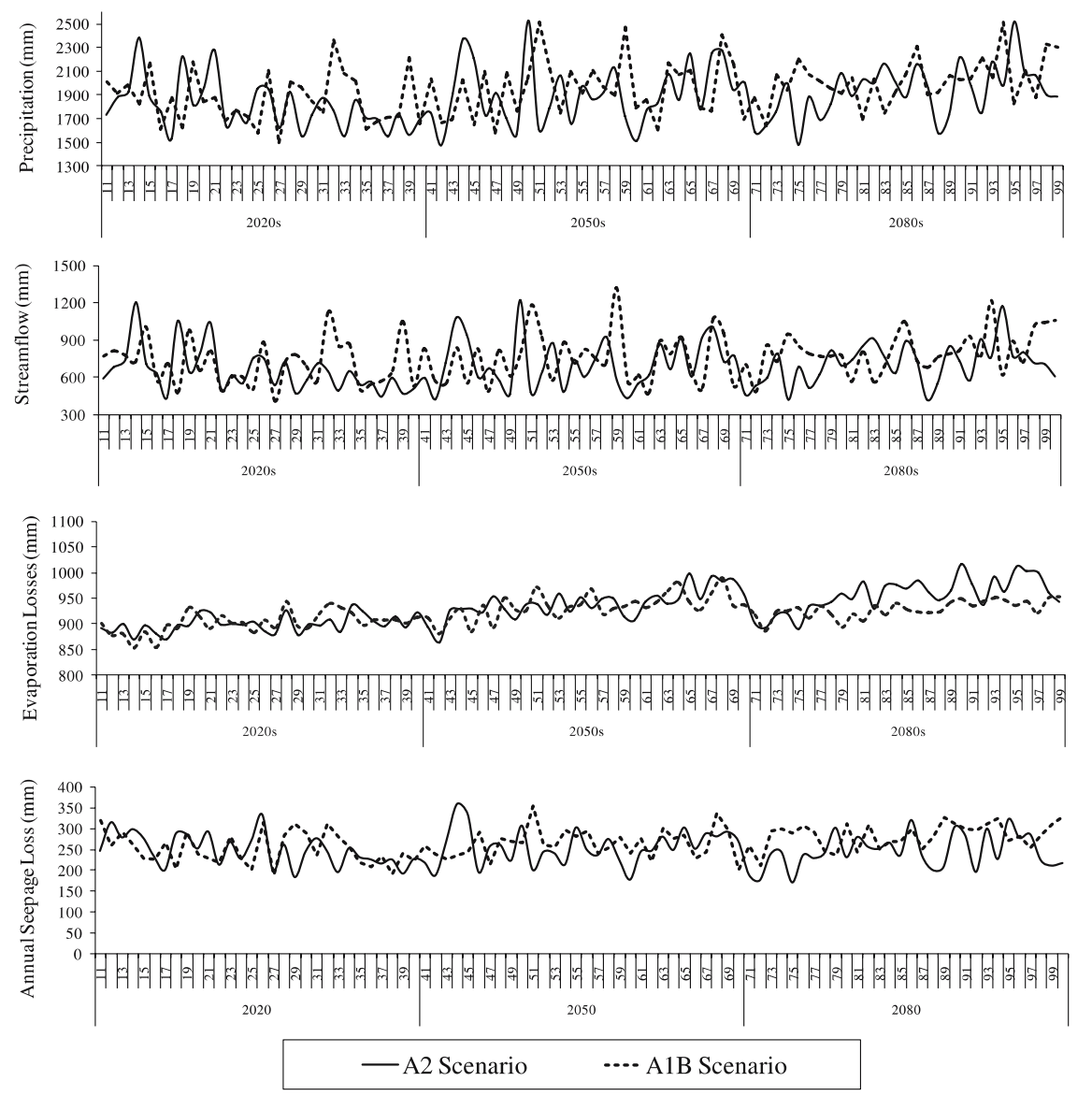

Figure 8. Water balance components responses and trends under the two CGCM3 scenarios.

For evaporation, the simulated fluctuations confirmed an increasing trend in all periods but the discrepancy of the two scenarios was more obvious in the 2080s period. The average periodic evaporation losses were calculated approximately at $860 \mathrm{~mm}$ (the 2020s), $884 \mathrm{~mm}$ (the 2050s), and $873 \mathrm{~mm}$ (the 2080s) for the A2 scenario, and $863 \mathrm{~mm}$ (the 2020s), $879 \mathrm{~mm}$ (the 2050s), and $849 \mathrm{~mm}$ (the 2080s) in the A1B scenario.

In addition, the evaporation rate relatively increased over the periods by almost $12-14 \%$ but appeared more evidently in the A2 scenario. Consequently, an overall small increase in the seepage losses was predicted at about $4-25 \%$ for the A1B scenario and $3-11 \%$ under A2 scenario, but unevenly distributed within a year in the watershed. In general, the seepage response appeared quite stable in the given forest watershed.

Figure 9 exhibits the monthly distribution of the water balance fluxes and scenarios in different periods. The 2020s period simulation shows dry period from January to April and wet period starting as early as May, low flows in January until September, low evaporation losses from October to April which remain high for the other months, and stable seepage with peak loss occurring in November. In the mid-century, there was a slight increase in the amount of rainfall (2.9-5.5\%), but decrease in the total amount of streamflow (1.5-6.6\% decreased) and increase in evaporation (12.8-13.5\%) and seepage (8.7-12.6\%) components. Furthermore, simulations show increase in May streamflow for both scenarios.

At the end of the period, it was predicted with two reasonably different patterns typically in all water balance components. The A1B scenario that demonstrated an initial peak flow in May corresponds to $37 \%$ increase over the current period with minimal recession until September, and significant increase from October until attaining its maximum peak flows $(192 \mathrm{~mm})$ in November. An increase in precipitation is attributed to the increase of streamflows $(8 \%)$, increase in evaporation $(9 \%)$, and increase in seepage $(25 \%)$.

In contrast, the A2 scenario simulation of streamflows dramatically decreased for almost eight months and deeply increased starting October with the peak flow in November. As a result, the disproportionate distribution of streamflows was attributed to a decline in seepage that occurred almost two times from April to October, 

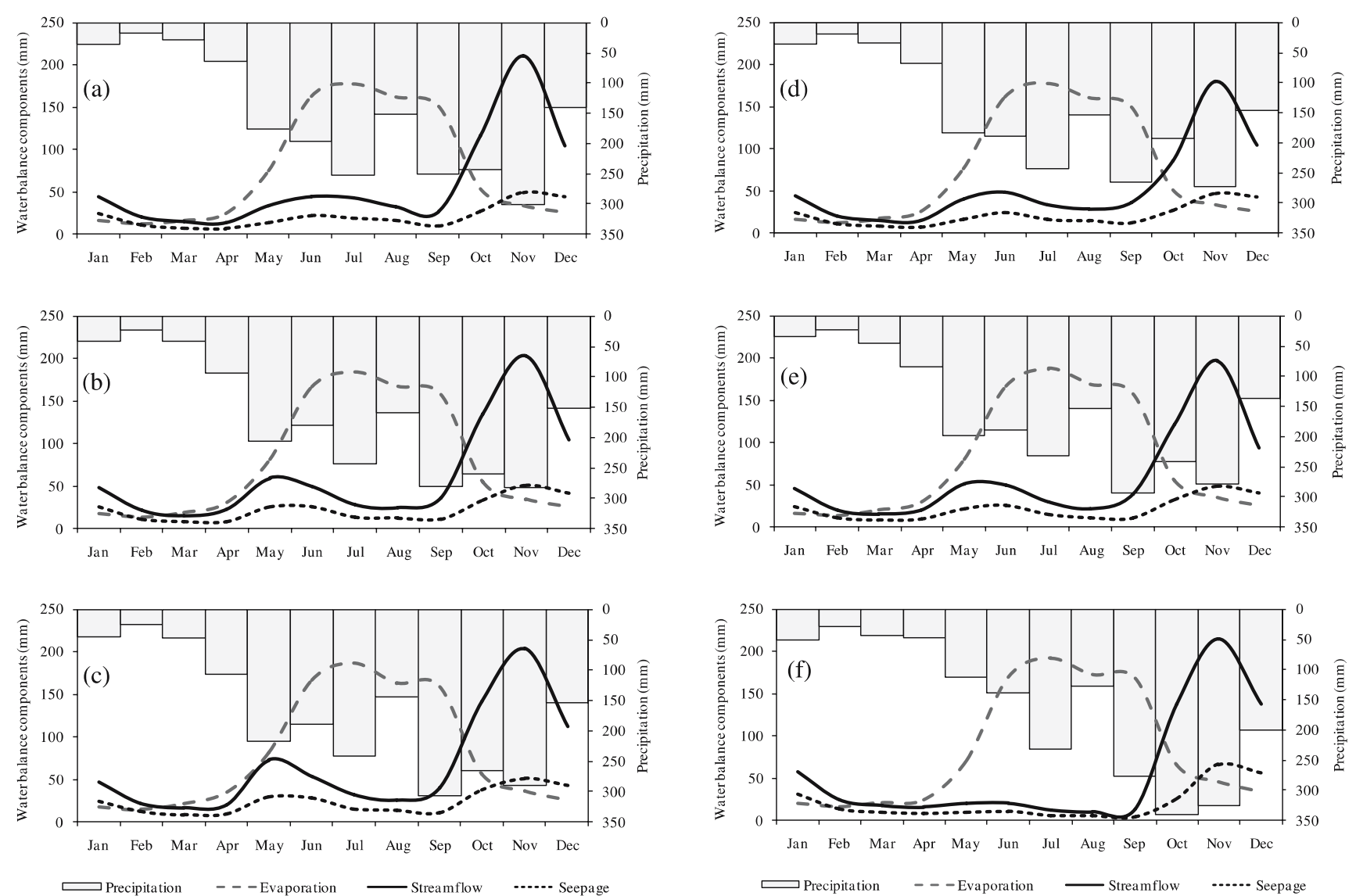

Figure 9. General trend of the monthly water balance fluxes in different periods corresponding to two climate change scenarios under the tropical forest watershed conditions. (a), (b), and (c) represent the 2020s, the 2050s, and the 2080s periods under the A1B scenario, respectively. The opposite side (d), (e), and (f) show results for the 2020s, the 2050s, and the 2080s periods of the A2 scenario, respectively.

while the major increase took place in November to January.

The outcomes of the simulation conformed to the IPCC AR4 report (Meehl et al 2007) assessment that precipitation and evaporation are generally projected to increase in the tropical Pacific. The intensity of precipitation events, which will be concentrated during September to November in the watershed, was anticipated to increase mean precipitation for short periods of time and then gradually fluctuate in recession years.

The study estimated high evaporation rates, which will be a major contributor to the loss of water from the given forest watershed. An examination of the changes in monthly evaporation rates provided an insight into the hydrologic changes in the watershed system under two climate change scenarios. Apparently, the tendency for dry periods is longer, indicating a greater risk of droughts in the watershed. Hence, changes in evaporation rates under the two scenarios were driven mainly by increasing temperature and precipitation fluctuations.

\section{Conclusions}

The distribution of water balance components is a primary concern for forests and their environment in the future. In this study, water balance components were evaluated in response to the plausible climate change. The statistical downscaling approach was utilized to derive finer and reliable estimate of hydrologic variables using predictors obtained from the CGCM3 experiment. The future weather under two different scenarios was studied. The hydrologic model was calibrated and validated at a catchment scale. Hydrologic changes between existing and future water balance components were investigated using two climate scenarios.

The results demonstrated that the simulation approach may give realistic estimates of water balance in a forest watershed under tropical conditions. The calibration of the BROOK90 model was very distinct on two pronounced seasonal variations.

The temporal distribution of water balance was greatly affected by changing climate, which has profound impacts on the hydrologic regimes even 
in the forested watershed. The hydrologic processes in the study watershed are likely to be altered under climate change. There is possibility for concentrated and extreme peak flow occurrences in the months of November.

More intense hydrologic events, such as extreme rainfalls, fluctuating streamflow magnitudes, and increasing evaporation losses, are expected to occur more frequently. This could place severe damage on the sustainability of agricultural production, onsite biodiversity, livelihood, and the environment in and around the watershed. The projected impacts on the forest watershed hydrology should serve as baseline information for mitigating effects of climate change.

The present investigation is in a forest watershed where potential impacts of the changing climate on water balance will probably be more intense if watershed undergoes large changes in land cover and land use conditions. Hence, the study concludes that future management strategies should focus on controlling population growth, which has direct association to anthropogenic factors thereby avoiding possible adverse impacts of changing climate on the site.

The study recommends the model and the approach be adopted for grasslands and denuded watersheds in multiple sites which could have different climate change impacts. In addition, the ability of the model to capture the water balance of the changing region needs to be improved taking into consideration longer calibration and validation periods since data monitoring is done continuously at the site. The application of physically-based hydrologic models as compared to the present study is necessary to fully capture intense seasonal variations and spatial influences. Finally, uncertainties associated in using a single GCM and a single-site need to be considered and are deferred for future work.

\section{Acknowledgements}

This study is an initiative of the Center for Restoration of Forest Ecosystem Functions on Different Forest Zones (CERES) project headed by Prof. Don Koo Lee, Seoul National University, with the support of the Forest Science and Technology Projects (Project No. S210608L0101704C) provided by the Korea Forest Service. We would also like to extend our deepest appreciation to the three anonymous reviewers for their valuable comments and suggestions to improve the paper.

\section{References}

Anandhi A, Srinivas V V, Nanjundiah R S and Kumar D N 2008 Downscaling precipitation to river basin in India for
IPCC SRES scenarios using support vector machine; Int. J. Climatol. 28 401-420.

Anunciado I M L 1993 Influence of forest land use change on agricultural production: The case of Sipit watershed Mount Makiling, Philippines, MSc Thesis, UP Los Banos, College, Laguna, 183pp.

Armbruster M K, Feger H and Seegert J 2004 Effects of changes in tree species composition on water flow dynamics - model applications and their limitations; Plant and Soil. 64 13-24.

Asokan S M and Dutta D 2008 Analysis of water resources in the Mahanadi River Basin, India under projected climate conditions; Hydrol. Process. 22 3589-3603.

Arnell N W 1999 A simple water balance model for the simulation of streamflow over a large geographic domain; J. Hydrol. 217 314-335.

Band L, Mackay D, Creed I, Semkin R and Jeffries D 1996 Ecosystem processes at the watershed scale: Sensitivity to potential climate change; Limnol. Oceanogr. 5 928-938.

Bae K K 2008 Stand structure, soil respiration and soil properties in secondary forest and agroforestry sites of Gmelina arborea and Dipterocarps after forest fire at Mt. Makiling, Philippines, MSc Thesis, Seoul National University, Seoul, Korea, 74pp.

Bantayan N C 2001 Geomatics-assisted impact assessment of land use change on the biodiversity of Mt. Makiling, Philippines; In: Proceeding of the 22nd Asian Conference on Remote Sensing 5-9 November 2001 Singapore; http://www.aars-acrs.org/acrs/proceeding/ACRS2001/ Papers/LUC1-01.pdf (January 6, 2007).

Bantayan N C and Bishop I D 1998 Linking objective and subjective modeling for land use decision-making; Landscape Urban Plan. 43 35-48.

Bari M A and Smettem K R J 2006 A conceptual model of daily water balance following partial clearing from forest to pasture; Hydrol. Earth Syst. Sci. 10 321-337.

Bates B C, Kundzewicz Z W, Wu S and Palutikof J P 2008 Climate Change and Water; Technical Paper of the Intergovernmental Panel on Climate Change, IPCC Secretariat, Geneva, 210 pp.

Brooks R H and Corey A T 1964 Hydraulic properties of porous media; Hydro. Pap. 3 1-27.

Brierly G J and Fryirs K 2005 Geomorphology and river management, Applications of the river styles framework (Oxford: Blackwell).

Calder I R, Wright I R and Murdiyarso D 1986 A study of evaporation from tropical rain forest-West Java; J. Hydrol. 89 13-31.

Campbell G S 1974 A simple method for determining unsaturated conductivity from moisture retention data; Soil Sci. 117 311-314.

Chen Y D, Chen X, Xu C Y and Shao Q 2006 Downscaling of daily precipitation with a stochastic weather generator for the subtropical region in South China; Hydrol. Earth Syst. Sci. Discuss. 3 1145-1183.

Cheng J D, Lin L L and Lu H S 2002 Influence of forests on water flows from headwater watersheds in Taiwan; Forest Ecol. Manag. 165 11-28.

Christensen J H, Hewitson B, Busuioc A, Chen A, Gao X, Held I, Jones R, Kolli R K, Kwon W T, Laprise R, Magaña Rueda V, Mearns L, Menéndez C G, Räisänen J, Rinke A, Sarr A and Whetton P 2007 Regional climate projections; In: Climate Change 200\%: The Physical Science Basis. Contribution of Working Group I to the Fourth Assessment Report of the Intergovernmental Panel on Climate Change (eds) Solomon S, Qin D, Manning M, Chen Z, Marquis M, Averyt K B, Tignor M and Miller H L, Cambridge University Press, Cambridge, United Kingdom and New York, USA. 
Clapp R B and Hornberger G M 1978 Empirical equations for some soil hydraulic properties; Water Resour. Res. 14 601-604.

Combalicer E, Im S, Lee S, Ahn S and Kim D Y 2008 Modeling water balance for the small-forested watershed in Korea; KSCE J. Civil Eng. 5 339-348.

Conway D, Wilby R L and Jones P D 1996 Precipitation and air flow indices over the British Isles; Clim. Res. 7 169-183.

CRU-WWF 1999 Climate change scenarios for the Philippines; http://www.cru.uea.ac.uk (August 30, 2006).

Cruz R V O 1982 Hydrometereological characteristics of selected upland cropping systems in Mt. Makiling; MSc Thesis, UP Los Banos, College, Laguna, 160p.

Diaz-Nieto J and Wilby R L 2005 A comparison of statistical downscaling and climate change factor methods: Impacts on low flows in the River Thames, United Kingdom; Climatic Change $69245-268$.

Dibike Y B and Coulibaly P 2005 Hydrologic impact of climate change in the Saguenay watershed: Comparison of downscaling methods and hydrologic models; J. Hydrol. 307 145-163.

Eckhardt K and Ulbrich U 2003 Potential impacts of climate change on groundwater recharge and streamflow in a central European low mountain range; J. Hydrol. 284 $244-252$.

Environmental Forestry Programme 2002 Watershed management research in the Philippines: Abstracts, needs and priorities; College of Forestry and Natural Resources. UP Los Banos, Philippines.

FAO 2007 State of the world's forests 2007; Food and Agriculture Organization of the United Nations, Rome, Italy, $144 \mathrm{p}$.

Federer C A, Vörösmarty C and Fekete B 1996 Intercomparison of methods for calculating potential evaporation in regional and global water balance models; Water Resour. Res. 23 15-21.

Federer C A 2002 BROOK 90: A simulation model for evaporation, soil water, and streamflow; http://home.maine. rr.com/stfederer/b90doc.html (August 30, 2007).

Federer C A, Vörösmarty C and Fekete B 2003 Sensitivity of annual evaporation to soil and root properties in two models of contrasting complexity; J. Hydrometeorol. 4 1276-1290.

Fernando E S, Sun B Y, Suh M H, Kong H Y and Koh K S 2004 Flowering plants and ferns of Mt. Makiling; ASEAN-Korea Environmental Cooperation Unit, Seoul National University, Seoul, Korea, 368p.

Field C B, Jackson R B and Mooney H A 1995 Stomatal responses to increased $\mathrm{CO}_{2}$ : Implications from the plant to the global scale; Plant Cell Environ. 18 $1214-1225$

Flato G M 2005 The Third Generation Coupled Global Climate Model (CGCM3); http://www.cccma.bc.ec.gc.ca/ models/cgcm3.shtml (August 8, 2008).

Flato G M and Boer G J 2001 Warming asymmetry in climate change simulations; Geophys. Res. Lett. 28 195-198.

Fleming M and Neary V 2004 Continuous hydrologic modelling study with the hydrologic modelling system; J. Hydrol. Eng. 5-6 175-183.

Fowler H, Blenkinsop S and Tebaldi C 2007 Linking climate change modelling to impact studies: Recent advances in downscaling techniques for hydrological modelling; Int. J. Climatol. 27 1547-1578.

Ghosh S and Mujumdar P P 2008 Statistical downscaling of GCM simulations to streamflow using relevance vector machine; Adv. Water Resour. 31 132-146.
IPCC 2001a Climate Change 2001: Synthesis report, (eds) Watson $\mathrm{R} \mathrm{T}$ and the Core Writing Team; In: Intergovernmental Panel on Climate Change, Cambridge University Press, Cambridge, UK and New York, 398pp.

IPCC 2001b Climate Change 2001: The Scientific Basis, (eds) Houghton J T, Ding Y, Griggs D J, Noguer M, van den Linden P J, Dai X and Johnson C A; In: Intergovernmental Panel on Climate Change, Cambridge University Press, Cambridge, UK and New York, 881pp.

IPCC 2007 Summary for policymakers; In: Climate Change 200\%: The physical science basis, Contribution of Working Group I to the Fourth Assessment Report of the Intergovernmental Panel on Climate Change (eds) Solomon S, Qin D, Manning M, Chen Z, Marquis M, Averyt K B, Tignor $\mathrm{M}$ and Miller H L, Cambridge University Press, Cambridge, United Kingdom and New York, USA.

Ito A and Oikawa T 2002 A simulation model of the carbon cycle in land ecosystems (Sim-CYCLE): A description based on dry-matter production theory and plot-scale validation; Ecol. Model. 151 147-179.

Jost G T, Heuvelink G B M and Papritz A 2005 Analysing the space-time distribution of soil water storage of a forest ecosystem using spatio-temporal kriging; Geoderma 128 258-273.

Karamouz M, Imen S and Nazif S 2007 Climate change and water availability; Second International Conference on Earth System Modelling (ICESM), ICESM Abstracts 1 ICESM2007-A-00046.

Karl T R, Wang W C, Schlesinger M E, Knight R W and Portman D 1990 A method of relating general circulation model simulated climate to the observed local climate. Part I: Seasonal statistics; J. Clim. 10 1053-1079.

Katz R W and Parlange M B 1996 Mixtures of stochastic processes: Applications to statistical downscaling; Clim. Res. 7 185-193.

Khan M S, Coulibaly P and Dibike Y 2006 Uncertainty analysis of statistical downscaling methods; J. Hydrol. $319357-382$.

Klinge R, Schmidt J and Fölster H 2001 Simulation of water drainage of a rain forest and forest conversion plots using a soil water model; J. Hydrol. 246 82-95.

Lasco R D, Guillermo I Q, Cruz R V, Bantayan N C and Pulhin F B 2004 Carbon stocks assessment of a secondary forest in Mount Makiling forest reserve, Philippines; J. Trop. For. Sci. 1 35-45.

Lee K W 2006 Ecosystem structure and functions in relation to restoration of degraded tropical forests in the La Mesa watershed and Mt. Makiling, Philippines; PhD Dissertation, Seoul National University, Seoul, Korea, 187pp.

Li X, Yang X and Gao W 2006 An integrative hydrological, ecological and economical (HEE) modelling system for assessing water resources and ecosystem production: Calibration and validation in the upper and middle parts of yellow river basin, China; Proc. of SPIE 6298 6298211-629821-12.

Lu S Y and Tang K J 1995 Study on rainfall interception characteristics of natural hardwood forest in central Taiwan; Bull. Taiwan Forest. Res. Inst. 4 447-457.

Marshall E and Randhir T 2007 Effect of climate change on watershed system: A regional analysis; Climatic Change doi: $10.1007 /$ s10584-007-9389-2.

Meehl G A, Stocker T F, Collins W D, Friedlingstein P, Gaye A T, Gregory J M, Kitoh A, Knutti R, Murphy J M, Noda A, Raper S C B, Watterson I G, Weaver A J and Zhao Z C 2007 Global Climate Projections; In: Climate Change 200\%: The Physical Science Basis. Contribution of Working Group I to the Fourth Assessment Report of the Intergovernmental Panel on Climate Change, (eds) Solomon S, Qin D, 
Manning M, Chen Z, Marquis M, Averyt K B, Tignor M and Miller H L; Cambridge University Press, Cambridge, United Kingdom and New York, USA.

Morison J I L 1987 Intercellular $\mathrm{CO}_{2}$ concentration and stomatal response to $\mathrm{CO}_{2}$; In: Stomatal Function; (eds) Zeiger E, Cowan I R and Farquhar G D; Stanford University Press, Stanford, USA, 229-251.

Mun C Y 1987 Rainfall and streamflow analysis of a large tropical rainforest watershed; MSc Thesis, UP Los Banos, College, Laguna, 156pp.

Nash J E and Sutcliffe J E 1970 River flow forecasting through conceptual models part I - a discussion of principles; J. Hydrol. 10 282-290.

Oh S N 1999 A bio-climatic assessment on urban area at Seoul based on observations and numerical simulations. http://klter.kookmin.ac.kr/EVENTS/Conference00/ html/osungnam.htm (October 3, 2007).

Palis H G 1991 Canopy hydrology of a Mahogany (Swietenia macrophylla King) plantation; SYLVATROP Tech. J. for the Philippine Ecosystems and Nat. Res. 1 1-7.

Pasa A E 1997 Effects of rainfall and watershed characteristics on the Molawin watershed; MSc Thesis, UP Los Banos, College, Laguna, 86pp.

Pancho J V 1983 Vascular flora of Mt. Makiling and vicinity (Luzon: Philippines) Part I; Kalikasan 1 476p.

Pritchard S G, Rogers H H, Prior S A and Peterson C M 1999 Elevated $\mathrm{CO}_{2}$ and plant structure: A review; Global Change Biol. 5 807-837.

Pudasaini B P 1993 Land capability classification and land use suitability assessment in Mount Makiling forest reserve using geographical information system; MSc Thesis, UP Los Banos. College, Laguna, 90pp.

Pullen S 2000 Options for obtaining vegetation information operationally from satellite observations; Satellite Imagery Applications Group, NWP Division, Bracknell, UK, 22pp.

Ramirez J A 2000 Prediction and modelling of hydrology and hydraulics, Chapter 11 of Inland Flood Hazards: Human, riparian and aquatic communities, (ed.) Ellen W, Cambrige University Press.

Saplaco S R 1983 Microclimate profile of a man-made dipterocarp forest in Mt. Makiling; The Philippine Lumberman 5 25-30.

Saplaco S R and Aquino M 1991 Hydrometeriological characterization of upland ecosystems at Mt. Makiling; Tropical Ecology and Development. University of the Philippines at Los Banos, 160pp.

Saxton K E and Rawls W J 2006 Soil water characteristic estimates by texture and organic matter for hydrologic solutions; Soil Sci. Soc. Am. J. 70 1569-1578.

Saxton K E, Rawls W J, Romberger J S and Papendick R I 1986 Estimating generalized soil water characteristics from texture; Trans. Amer. Soc. Agri. Eng. 4 $1031-1035$

Schubert S and Henderson-Sellers A 1997 A statistical model to downscale local daily temperature extremes from synoptic-scale atmosphere circulation patterns in the Australian region; Clim. Dynam. 13 223-234.
Shuttleworth W J and Wallace J S 1985 Evaporation from sparse crops - an energy combination theory; Quart. J. Roy. Meteor. Soc. 111 839-855.

Tabios G Q 1978 Stochastic hydrology of daily streamflows; MSc Thesis, UPLB, College, Laguna, 158pp.

Tripathi S, Srinivas V V and Nanjundiah R S 2006 Downscaling of precipitation for climate change scenarios: A support vector machine approach; J. Hydrol. 330 621-640, doi:10.1016/j.jhydrol.2006.04.030.

UNEP 2007 Addressing the leadership challenge of climate change; United Nations Headquarters, New York, Fact Sheet, $15 \mathrm{pp}$.

USEPA 2004 Global warming site; http://yosemite.epa.gov/ oar/globalwarming.nsf/ content/index.html (January 15, 2008).

Vallesteros A P 2002 GIS-based determination of socioeconomic variables affecting land-use change in Mt. Makiling forest reserve, Philippines; MS Thesis, UPLB, College, Lag. Phil, 129pp.

Vilhar U, Simoněiě P, Kajfež-Bogataj L, Katzensteiner K and Diaci J 2006 Influence of forest management practice on water balance of forests in the Dinaric Karst; All about Karts and Water 290-295. http://petelin.gozdis.si/ splet/dokument.php?id=21 (August 30, 2007).

Vogel M R, Wilson I and Daly C 1999 Regional regression models of annual streamflow for the United States; J. Irrig. Drain. Eng. 5-6 149-157.

Wahren A, Schwärzel K, Feger K H, Münch A and Dittrich I 2007 Identification and model based assessment of the potential water retention caused by land-use changes; Adv. Geosci. 11 49-56.

Wand S J E, Midgley G F, Jones M H and Curtis P S 1999 Responses of wild $\mathrm{C} 4$ and $\mathrm{C} 3$ grass (Poaceae) species to elevated atmospheric $\mathrm{CO}_{2}$ concentration: A metaanalytic test of current theories and perceptions; Global Change Biol. 5 723-741.

Wang Q, Adiku S, Tenhunen J and Granier A 2005 On the relationship of NDVI with leaf area index in a deciduous forest site; Remote Sens. Environ. 94 244-255.

Wilby R L and Dawson W 2007 SDSM 4.2 - A decision support tool for the assessment of regional climate change impacts (User Manual); Climate Impacts and Adaptation Research Programme, Environment Agency of England and Wales, UK, 94pp.

Wilby R L, Dawson C W and Barrow E M 2001 SDSM A decision support tool for the assessment of regional climate change impacts; Environ. Model. Softw. 17 $145-157$.

Wilby R L, Charles S P, Zorita E, Timbal B, Whetton P and Mearns L O 2004 Guidelines for use of climate scenarios developed from statistical downscaling methods; Environment Agency of England and Wales, UK, 27pp.

Wilby R L, Hassan H and Hanaki K 1998 Statistical downscaling of hydrometeorological variables using general circulation model output; J. Hydrol. 205 1-19.

Young A R 2006 Stream flow simulation within UK ungauged catchments using a daily rainfall-runoff model; J. Hydrol. 320 155-160. 